\title{
Assessment, Testing and Correcting Students' Errors and Mistakes
}

\author{
ARBURIM ISENI \\ Senior Lecturer, State University of Tetova, Macedonia
}

\begin{abstract}
Bio Data:
Arburim Iseni holds the degree Master of Philological Sciences in TEFL from Prishtina University-Republic of Kosova and is a Senior Lecturer at the Department of English Language and Literature - State University of Tetova - Macedonia. At present he teaches Basics of English Grammar, English Morphology and English Syntax at the State University of Tetova. He taught English courses at South East European Private University in Tetova where he is doing his $\mathrm{PhD}$ in Applied Linguistics - Second Language Acquisition. From 2009 he is Chief of the English Department at the State University of Tetova, Faculty of Philology. He has also published papers in journals such as Porta Linguarum, Winds Of New Zealand, SUT Scientific Obsevrer, ID EST, etc.
\end{abstract}

\begin{abstract}
This study is the result of continuous four-year work in the field of noting and reviewing of errors in learning English. The object of this research were 50 students at the State University of Tetova who study English. In this work were studied errors made by students during tests, interviews, dictations, writing paragraphs and different essays. If in the spoken language errors can be allowed without being corrected, as long as the message comes clear, it is understood that in the written work errors should be corrected more carefully, because if they are left without correction, these errors can become fossilized. For the objective of our work it was important to attempt to find the most appropriate strategy to correct errors and mistakes and the best way to assess our students' writings. Thus, this study is a modest contribution that, in the first place, should be taken as an incentive and orientation for new lecturers and researchers to improve their work regarding the attitude that should be held towards errors and mistakes of our students.
\end{abstract}

Keywords: assessment, evaluation, testing, errors, mistakes, etc.

\section{Introduction}

Assessment is often equated and confused with evaluation, but the two concepts are different. Assessment is used to determine what a student knows or can do, while evaluation is used to determine the worth or value of a course or program. Assessment data effects student advancement, placement, and grades, as well as decisions about instructional strategies and curriculum (Herman and Knuth 1991). 
Assessment is a powerful force in student learning. From the students' perspective only the most important activities in a subject are assessed (Peter Kandlbilder, 2009). Moreover, he then states that "Simply by changing the assessment of your subject you can affect the way students engage with the subject content." He also adds that "A review of the literature shows that finding the right balance of student workload, goal alignment and formative feedback is likely to have the greatest impact on improving student learning."

\section{The Study}

This study aims to investigate assessment, testing and disagreement strategies used by Albanian speakers of English at State University of Tetova, English Department. The study includes 50 Albanian university students of the fourth year ( 5 males and 45 female students). The students' age is between 21-23 and they are all Albanians.

\section{Data Analysis}

The data was analyzed according to the responses obtained from the participants. All the participants were assessed with different tests and rubrics. These data were analyzed and evaluated and students were monitored in every class each semester during the whole year.

How can assessment help in correcting students' errors and mistakes? An important part of helping students in language learning is helping them learn from their errors and mistakes. Testing and assessment are essential for helping students progress in their language learning. In order to actively develop student learning we need the students to be highly motivated (Greer, 2001, pp. 127) and to fully commit to the assessment processes.

What is assessment/evaluation? According to Palomba, C.A. and Banta, T.W. $(1999,4)$ "Assessment is the systematic collection, review, and use of information about educational programs undertaken for the purpose of improving learning and development." Assessment is of central importance. Every teacher has an interest in knowing whether, and to what degree, his/her teaching has been successful. Whereas according to Imran Hameed "Educational assessment is the process of documenting, usually in measurable terms, knowledge, skills, attitudes and beliefs" (Wikipedia 2009). In their lecture presentation titled 'Authentic Assessment?!? My plate is already full!', Rita M. Purcell-Robertson and Michele Wiley from the Loudoun County Public Schools, state that "assessment can focus on the individual learner, the learning community (class, workshop, or other organized group of learners), the institution, or the educational system as a whole." Furthermore, Maria Arias Cordova (2010: 50-64) says that "assessment is generally used to refer to all activities teachers use to help students learn and to gauge student progress." Whereas according to Harlen, Gipps, Broadfoot, Nuttal (1992, pp. 219) “Assessment in education is the process of gathering, interpreting, recording, and using information about pupils' responses to an educational task." William M. K. Trochim (2006) in his article "Introduction to Evaluation" states that "Evaluation is the systematic acquisition and assessment of information to provide useful feedback about some object." 
Evaluation not only measures how well we are doing, but also helps us to be more effective. Evaluation has two main purposes: for learning and development.

Monitoring and evaluating our work will help us assess how well we are doing in order to help us do it better. It is about using evaluation to learn more about our activities, and then using what has been learnt. According to Alexis W. (2011) 'Educational evaluation is the process by which teachers, schools, and students are evaluated to indicate the effectiveness of education and the degree to which students integrate and understand information.'

Anthony Fredericks (2005, pp. 99-112) states that "effective evaluation is a continuous, on-going process." Then, he adds that "Evaluation must be a collaborative activity between teachers and students. As regards students he says that "they must be able to assume an active role in evaluation so they can begin to develop individual responsibilities for development and self-monitoring." Furthermore, as regards evaluation he says that "evaluation needs to be authentic."

Evaluation must be based on the natural activities and processes students do both in the classroom and in their everyday lives. Also according to him, "evaluation is more complex than writing a test, giving it to a group of students, scoring it, and handing it back with some sort of letter grade." Indeed, evaluation involves a combination of procedures and designs that not only measures students' work but also helps them grow in the process (TeacherVision, n.d.).

\section{Principles of Assessment}

According to Tracey Hall, et al., (2009, pp. 2) "not all students are alike." Therefore, in order to best promote learning and to give a valid picture of individual achievement, the assessment and evaluation process should incorporate the following principles: assessment process should be planned and communicated to learners and parents prior to instruction; assessment strategies must align with the prescribed curriculum objectives and with the teaching strategies used; assessment must be fair and designed to enable each student to demonstrate the full extent of their own learning; assessments should measure how well students learn as well as what they have learned; assessment instrument should be highly varied in type; assessments should cover a full range of instructional objectives including knowledge, skills, and affective items; assessment should be continuous; students should peer-assess, self-assess, and set personal achievement goals; students must receive clear instructions for improvement in what they have learned as well as how they learn.

Nel (2010) disagrees with the statements of Angelo, T. and Cross, K.P., (1993, pp. 427) given in their handbook entitled "Classroom assessment techniques a handbook for college teachers" as regards these two terms, they state, as follows: "Assessment focuses on learning, teaching and outcomes." Furthermore, they state that "assessment provides information for improving learning and teaching." Whereas as regards evaluation, they claim that "evaluation focuses on grades and may reflect classroom components other than course content and mastery level." Additionally, they say that "the overall goal of assessment is to improve student learning." Subsequently, they claim that "assessment requires the gathering of evidence of student performance over a period of time to measure learning and 
understanding." According to them, "an evidence of learning could take the form of dialogue, journals, written work, portfolios, tests, along with many other learning tasks." As effective teachers one should use assessment techniques regularly and on a daily basis to improve student learning and to guide instruction. By assessing the students and evaluating their oral or written work successively will enable the teacher to know exactly what will be their student's final grades.

\section{Assessment vs. Evaluation}

Moreover, Anthony D. Fredericks (2005, pp. 99112) as regards assessment states that "Assessment is, most likely, not a new concept for us; however, in most previous assessment situations, you were probably the one being tested."

Additionally, according to him as teachers "you will be required to determine how well your students are learning, estimate their performance, and measure the appropriateness of the content and the effectiveness of the methods and techniques utilized in your classroom."

He also advises us that "when you assess your individual students, you gather information about their level of performance or achievement."

As for evaluation he states that "evaluation is comparing a student's achievement with other students or with a set of standards." Also he determines the "Effective assessment as a continuous process and saying that it's not simply something that's done at

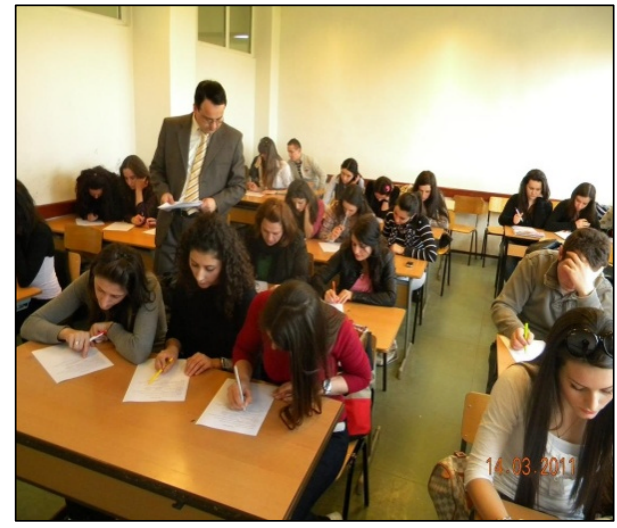

Photo 1. Assessment vs. Evaluation

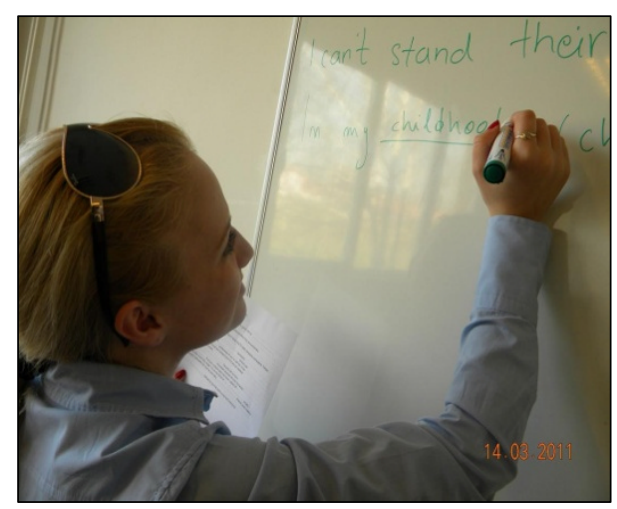

Photo 2. Assessing Individual Students the conclusion of a unit of study or at the end of a lesson." Then he supports it even more by saying that "Effective assessment and evaluation are integrated into all aspects of the curriculum, providing both teachers and students with relevant and useful data to estimate progress and determine the effectiveness of materials and procedures" (TeacherVision, n.d.).

According to Walvoord (2004), student outcomes assessment involves the following three steps:

1. Articulating goals and objectives for student learning

2. Gathering evidence about how well students are meeting the goals

3. Using the information to improve student learning (Source: assess.psu.edu) Sinclair Community College about Assessment and Evaluation states the following: "Assessment is the analysis and use of data by students, faculty, and/or departments to make decisions about improvements in teaching and learning." 
Whereas for Evaluation they state that "it is the analysis and use of data by faculty to make judgments about student performance." Furthermore, as they state, "evaluation includes the determination of a grade or a decision regarding pass/fail for an individual assignment or a course" (Source: sinclair.edu). According to MB MANUAL about Assessment \& Evaluation Processes Appendix A-1 as regards these two terms it is said that "Assessment has two meanings. The first meaning refers to a specific instrument of measure. Any test is an assessment. The second meaning refers to the process

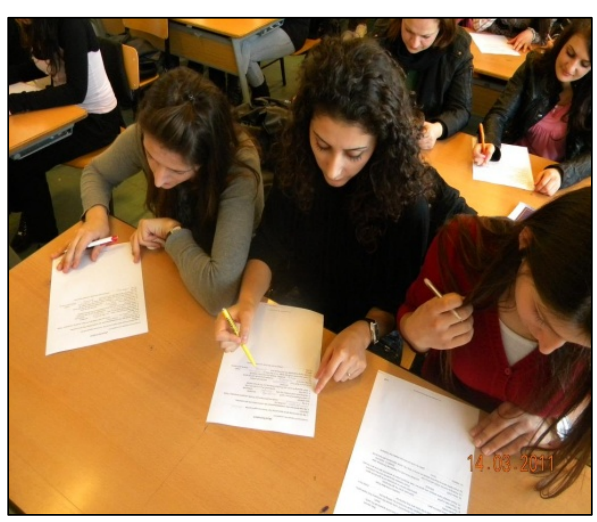

Photo 3. Effective Assessment of designing measurement instruments and then using them to gather critical appraisal data about each learner's progress." Whereas as regards Evaluation in this manual it is states that "Evaluation is sometimes used as a synonym for assessment. However, 'evaluation' implies an estimate of overall value whereas 'assessment' implies a specific measure. Educators must perform both processes." One should assess during the collection of achievement data and evaluate when determining the meaning or significance of the body of data collected. A teacher who is grading a student's test to come up with a percentage score is assessing. At report card time, the teacher will gather all of the student's assessment data and evaluate his/her overall performance. An 'assessment' is an individually measured item whereas an 'evaluation' is an estimate of the overall merit of the collection of assessed items.

Furthermore, in this manual it is stated that "evaluation requires professional judgment." Also, according to this manual it's not enough to look at a student's calculated arithmetic mean and blindly assign that number as the overall grade. In my experience, I evaluate students from each grading components that I establish in the syllabus and at the end in a cumulative way I precisely determine their grades. Thus, educators must analyze the body of growth evidence to look for patterns of 'central tendency.' When evaluating, the educator must answer a question: 'How well has this student acquired the curriculum?'

If the student has acquired it very well, a top grade from any of the scales above should be assigned. As teachers we should monitor the students because they want to know where they stand and yet each responds differently to evaluation.

We should always be careful because some students will regard a critical comment as a challenge that spurs them on to better work, while others are discouraged by criticism.

Therefore, these considerations need to be balanced against maintaining common,

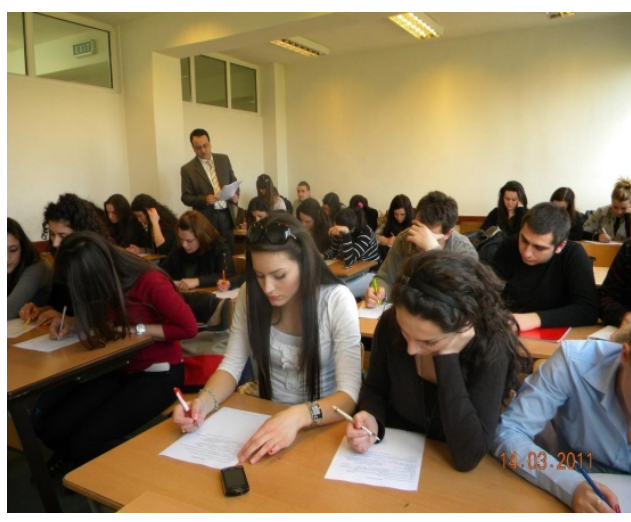

Photo 4. Teacher/peer/self-evaluation appropriate standards. The fifth principle is that assessment and evaluation should be balanced and comprehensive. 
Assessment and evaluation should be varied and balanced. For example, consideration should be given to Teacher/peer/self-evaluation. Teacher created assignments, tests, and observation criteria provide important evaluation information. Then, peer evaluation can provide many opportunities for extending learning and for increasing student confidence and involvement in the learning process. Finally, self-evaluation allows students to become aware of their own learning and to enhance it. Another consideration should be also given to Content/process/product. Thus when beginning with a subject, students must know what they are required to learn, and this has to do with the content of the subject, then they should be given an idea of how they are expected to learn, this has to do with the process, and finally what evidence they will be required to produce as a result of that understanding, and thus this is the product.

\section{Continuous Assessment}

Continuous assessment is an ongoing assessment and helps teachers to evaluate the learner's performance. It is based on observations of what students are doing. While examinations are one way of assessing learners, continuous assessment refers to what is taking place in the classroom on an ongoing basis. I use continuous assessment in the classroom to ensure that all my students are succeeding and in this way I can adopt my instructions to the needs of all my students. Thus, there are many reasons why I use continuous assessment in the classroom with my students. These reasons are as follows: to find out what students know and can do, to ensure ourselves in what we say our students know and can do, to provide all students with opportunities to show what they know, to promote learning for understanding, to improve teaching, to help determine what kind of remediation and enrichment activities to provide, and to identify which students need assistance, to let the students know how well they are progressing in their own learning, and to lead to overall evaluation.

\section{Testing vs. Correcting Errors/Mistakes}

Assessment in general is closely connected with Language Assessment, which can be done through language tests. A test is a method of measuring a person's ability or knowledge on a given domain. They are usually carefully designed and have identifiable scoring rubrics. Tests are prepared by administrators; students prepare for them, and they know that their answers will be measured through correcting errors and mistakes. A language test is a way to judge what students know, in order to help them improve their performance and give them a criteria for success.

\section{The Principles of Testing and Assessment for Correcting Students' Errors}

Why should we consider correcting written work?

- It is more of a problem with the students learning a foreign language.

- To help the teachers improve their work in this direction.

- To focus attention on accuracy and content.

- To help both teacher and students together correct written work and oral work. 
- To help teachers not only correct spelling, grammar, lexical and other mistakes but also these corrections might be accompanied by certain comments on the content of the written work, showing the student where the work was effective and where it was not.

There are different procedures to help teachers to correct written work.

Let us look at some of them:

1 - The correction of all the mistakes

2 - The correction of the mistakes selectively

3 - Underline the mistakes; write the nature of the mistake, the student has to correct them.

- First phase, underline the mistakes and write the right symbol in the margin on the same line.

- Second phase, underline the mistake and do not write the symbol. This helps the students find the type of the mistake themselves

- Third phase, write the symbol on the margin, next to the line where the mistake is, but do not show exactly where the mistake is, and show only the line. This helps the student find the mistake, helped by the symbol put on the margin.

- Fourth phase, put a cross $(X)$ on the margin, put as many crosses as mistakes are in a line. The students will find the mistake and the type, knowing how many mistakes are in one line.

- Fifth phase, put a cross next to the line in the margin, but do not show how many mistakes are. This is a more difficult way of correction; it makes the students think about mistakes, knowing that there is something wrong in a particular line.

4 - The teachers may leave the students find their own mistakes, leaving to them a certain amount of time to find and correct their mistakes, sometimes called selfcorrection.

1 - The correction of all mistakes. This is a traditional procedure for the correction of the mistakes in a written work. But it is often a waste of time for the teacher and a discouragement for the student if they receive their work full of red notes. Some students may react badly and thus learn nothing.

2 - The correction of the mistakes selectively. This procedure presupposes that the teacher corrects not all the mistakes but only those that the teacher has decided to focus on, for example, the tenses of the verbs, articles, etc. Certainly this procedure has more positive effects than the total correction, because the teacher focuses on a certain issue that he thinks the students need more. This way is more practical and more effective if the teacher has clear objectives.

3 - Underline the mistakes; write the nature of the mistake, the student has to correct them. This procedure is mainly done through symbols mentioned above to help the students focus their attention on the type of the mistake and think about how to correct it. It involves the student in correction and helps the teacher to find if the mistakes done by the students are errors or simply slips of pen. The symbols should be clear and meaningful. Before using them the teachers should explain the symbols to the students, till they become natural to their work. Using the list of symbols the students can work individually, in pairs or in small groups. They may 
identify themselves some of the mistakes; in case of need they may consult the teacher. This procedure makes the students more self-conscious of their mistakes and the correction might be more effective and fruitful.

4 - The teachers may leave the students find their own mistakes, leaving to them a certain amount of time to find and correct their mistakes, sometimes called self-correction. This may be done when the teacher has time to correct the mistakes in the class and to discuss them. It is effective but difficult to be applied. There are cases when the students enjoy this type of correction and work seriously. While using this procedure the teacher may help the students through

- Explaining the mistake, on the margin. This is done to attract the attention of the students for the type of the mistakes and for repeated mistakes. This also may be done when the teacher has time to discuss the mistakes in the class.

- Writing that the student needs to consult the teacher for some mistakes. This may be used as an alternative, not to be monotonous.

- Using the general mistakes to improve teacher's and students' work. This procedure may be used if a considerable number of students have made the same mistake, thus attracting the attention of the students for a general mistake.

The correction in this way may improve the presentation of the new lesson. There are cases that the teachers use only one way of correction, because they get used to it, it is easier and are swamped by routine.

There are also teachers that do not accept the self-correction procedure. Anyway we cannot say this is wrong and this is right. We may only offer alternatives for the correction procedures and let the teachers choose what they think is more suitable in their work. The procedure of self-

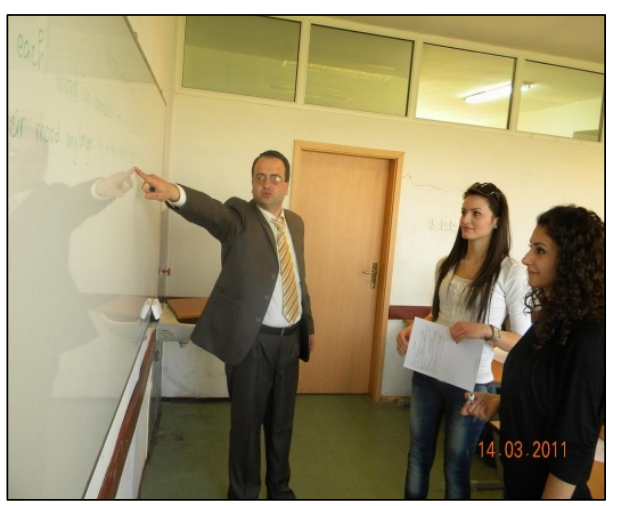

Photo 5. Identifying and correcting mistakes ${ }^{1}$ correction helps the students develop critical thinking towards their written work. Every teacher selects himself the procedures of correction the mistakes according to the interests and needs of his students. There is a general agreement among researchers that having the teacher correct every error on students' written work is not the most useful way of providing corrective feedback. This approach is time consuming and resembles editing more than it does correcting. Students may seem extremely discouraged if their papers are continually to them with so many red marks as there are words on a page. There is also good reason to believe that by supplying the corrections themselves, teachers might actually be hindering the students' progress in building proficiency in writing" (Pit Corder, "The Significance of Learner's Errors", 1999). Whatever procedure we use in correcting the written work of our students, we the teachers should bear in mind that we should allow students time to identify their mistakes and to correct them." In this way the teacher is acting as a resource and can help where students do not know what is wrong" (Jeremy Harmer, 1989).

Some advice for correction:

- Sit down and correct without laziness 
- Do not work under the pressure of time

- Concentrate on the main issues that help the students to improve their work and performance for the future issues

- Give the opportunity to the student to overlook his work

- Written comments is good to be followed by short discussions

- Give time to students to ask for the written comments

- Change the code of correction according to the level of the students, time you have at your disposal, type of mistakes, aim of correction, etc.

- Do some preparatory work before the students begin to write, this reduces the number of mistakes

- Share experiences with other teachers as far as error correction is concerned

- Offer to the students practical and clear comments, specific suggestions to improve their work

- Be positive and constructive in your comments, there is always something good in a student's work

- Before using the symbol code, explain it clearly to the students

- Plan to spend the necessary time in the class for self-correction

- Do not use scrubs, do not cross out whole paragraphs, write clearly, and possibly write with a different pen, not always red, as the students are tired of red notes. The student's work should not be a mess at the end of correction. Try not to write over student's writing

You may write these comments, try to be positive:

- Your work is expressive, challenging, and vital

- Well chosen vocabulary, natural, everyday life

- The sentences and paragraphs are effective

- Generally good, well, (implying not perfect)

- Your handwriting is not quite clear, understandable, etc. etc.

- You may add others and others

Try to shift the tendency of the teachers, who are over-preoccupied with accuracy." This means that the student's work is often covered with red ink and no comment is made about whether the work was interesting or successful" (Jeremy Harmer, 1989).

\section{Teaching principles, Testing, Correction and Assessment}

As a University teacher, my classes are implemented through building a positive relationships with and values of each student. Although this is a time consuming but still helps me create a positive atmosphere in the class and my students feel more comfortable to express themselves.

Then, I also promote a culture of value and respect for individuals, no matter from which community they come from. Through this principle, I create an environment where

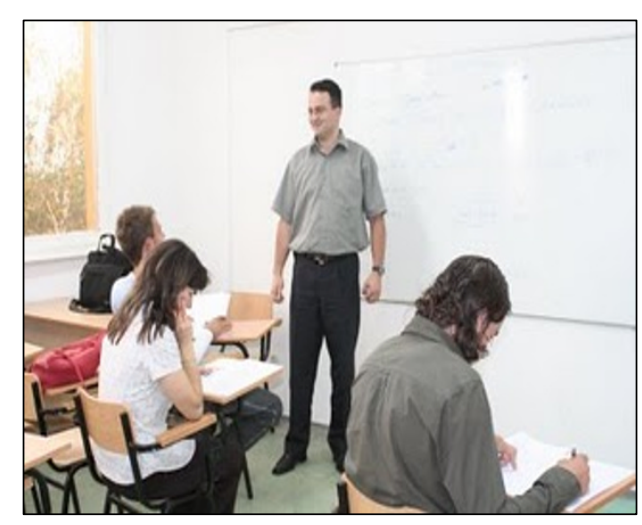

Photo 6. Promoting a culture of value and respect for individuals 
my students' comments are acknowledged equally. I also respect their opinions.

In my teaching classes I support my students a lot and this helps them to feel more confident and express their ideas without hesitation. What is more important I never put them down. I always encourage them to participate in my classes. Another principle that I use while teaching my students is valuing their efforts and recognizing positively their

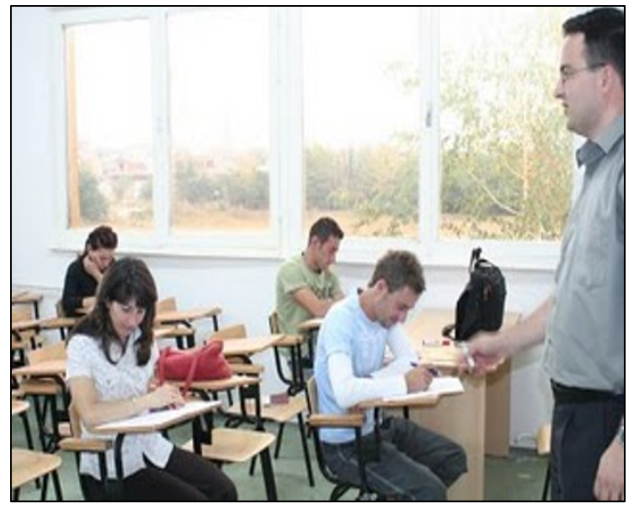
work both publicly and in personal feedback. I also Photo 7. Clarity of Instructions ${ }^{1}$ encourage my students by ensuring that they all have different abilities, therefore, I think they take more responsibility for their learning. Another principle of learning that I implement with my students is establishing clear criteria for assessment before I test them. I never test my students for something that I haven't taught them. I also use strategies to build skills for productive collaboration. By saying this, I mean maximizing engagement and interaction through group discussions, arranging them in panels or group tables. I am also using the strategy of being flexible with my students, and this helps me find their lacks and needs. Furthermore, I also use the principle of how students better approach learning through reveling their different abilities and strengths. This allows my students to experience diverse ways of learning and knowing. Thus, all these principles are aimed at course improvement rather than just assigning a grade to my students. As regards students, these principles of learning help them become better monitors of their own learning, break down feelings of anonymity, revealing the needs to alter their study skills, and also providing them the concrete evidence that as teachers we care about their learning. In order to receive a concrete evidence for them I prepare different kinds of tests, but always having in mind the reliability and validity of the test. By the term reliability of the test, I mean the clarity of instructions in it, test layout, type and length, etc. More importantly, I prepare tests which correlate with what has been taught. My students are also tested in all the language skills, such as: reading, writing, listening and speaking. On the other hand, with the term validity of the test, I mean how the original objectives of the test are measured. However, Genesee and Upshur (1996) as regards this issue they claim that "We can never be completely confident that the tests we create are in fact, both reliable and valid." In the case with error detection and their analysis, we always strive to prepare tests that would fulfill all the aspects of reliability and validity. Also, in order to get the adequate results, we set our testing objectives first.

\section{Results}

Usually, my tests are based both on my student's prior knowledge and on specific tasks. This helps me to easily notice their performance errors. I sometimes prepare tests with distracters in order to see if they have any prior knowledge for that. As regards my students and the results that I have presented so far, it can be seen that they get better over time, for instance, in spelling, because they are learned to correct their errors through self-and peer-assessment. Also, I used with them another strategy which was very essential and that is continuous assessment. According to Joy 
du Plessis, et al., (2003) in their IEQ project "Continuous Assessment: A Practical Guide for Teachers" as regards Continuous Assessment they state that: "Continuous Assessment is divided into two parts. The first part explains the main concepts of assessment and the importance of carrying out continuous assessment. It also explains the difference between exams and continuous assessment. The second part describes practical ways in which to carry out continuous assessment of learners in the classroom." In practicing this strategy, I ensured that all my students are progressing. Thus, I could see which students were struggling with a topic or skill; which aspects of the topics given to them were difficult; which student was grasping the topic and the skill well, and what was more important whether this strategy was effective at helping my students improve. I continuously ask my students to assess their friend's paper, because as far as I am concerned, when as a teacher you involve a student to assess another student's paper, this can help them become more analytical, and in this way they learn more and gain an understanding of their own progress, they learn how to be critical and analytical and they engage themselves in metacognition. Again, continuous assessment is essential, and many strategies can be used. The following are the strategies that I use with my students in order to make continuous assessment: checklists, anecdotal notes, portfolios, written assignments, self-assessments, peer assessments, teacher-constructed assessments, tests, interviews, conferences, reading logs, response journals, writing journals or notebooks, etc. 


\section{References}

Alexis, W. (2011). What is an educational evaluation? Retrieved from http:/ / www.wisegeek.com/what-is-an-educational-evaluation.htm Angelo, \& Cross. (1993). Classroom assessment techniques. San Francisco: Jossey-Bass. Benedetti, K. (2006). Language testing: Some problems and solutions. Universidad de Guanajuato: México.

Brown, D. B. (1994). Principles of language learning and teaching. New Jersey: Prentice Hall Regents.

Brudhiprabha, P. (1972). Error analysis. A psycholinguistic study of Thai English compositions. New York : McGill University.

Bueno, A., et al. (1992). Análisis de errores en inglés: tres casos prácticos. Granada: Servicio de Publicaciones de la Universidad.

Cabrejas, A. B. (2006). A comparison of the revising processes of Spanish speakers and English native writers: Similarities and differences. Valencia: Universidad de Valencia.

Çeliku, M. (2002). Gramatika e gjuhës shqipe" vëllimi I, II. Akademia e Shkencave e Shqipërisë. Instituti i Gjuhësisë dhe Letërsisë. Tiranë.

Clapham, C. (2003). Principles of assessment: Guide to good practice. Retrieved from www.llas.ac.uk/resources/gpg/1398

Clyne, S. (2002). Psychological factors in second language acquisition: Why Your international students are sudando la gota gorda (Sweating Buckets)? Retrieved from

http://www.bhcc.mass.edu/newsite/GI/DiversityandInclusion/TFOT_Psyc hFactors2ndLang.doc

Connoley, R. (2004). Criterion-Referenced Assessment. Australia: Deakin University.

Cook, V. J. (1993). Linguistics and language learning. Modern linguistics. New York:

St.Martin's Press.

Cook, V. J. (1999). Going beyond the native speaker in language teaching. TESOL Quarterly.

Corder, S. P. (1974). Error analysis. In J. P. B. Allen \& S. Pit Corder (Eds.), Techniques in applied linguistics. London: Oxford University Press.

Corder, S. P. (1967). The significance of learners' errors. International Review of Applied Linguistics, 5 (4).

Corder, S. P. (1971). Idiosyncratic errors and error analysis. IRAL.

du Plessis, J., Prouty, D., Schubert, J., Habib, M., \& St. George, E. (2003). Continuous Assessment: a practical guide for teachers. Washington, DC: American Institutes for Research with support from the U.S. Agency for International Development.

Ellington, H. (1987). Criterion-referenced assessment and norm-referenced assessment. Aberdeen: Robert Gordon's Institute of Technology.

Ellington, H. (1987). Student assessment. Teaching and learning in higher education. Aberdeen: Robert Gordon's Institute of Technology.

Hancock, C. R. (1994). Alternative assessment and second language study: What and why? ERIC Digest. Washington, DC: CAL.

Hernández Fernández, A. (2001). Los errores lingüísticos: Tipología y necesidad. Universidad de Granada. Tesis Doctoral. 
Hull, G. (1985). Research on error and correction. In B. McClelland \& T. Donovan (Eds.), Perspectives on research and scholarship in composition. New York.

Iseni, A. (2006). A practical English grammar. Çabej Publishing House: Tetova.

Iseni, A. (2006). An analysis of errors in Albanian speakers' English writings. University of Prishtina: Kosova.

Iseni, A. (2008). Modern English grammar. Tringa Publishing House: Tetovë.

Iseni, A. (2010). Error detection in the Albanian speakers' English writings. With special emphasis on morphological errors. Tetovo: The State University of Tetovo.

James, C. (1998). Errors in language learning and use: Exploring error analysis. London: Longman.

Joy du Plessis, et al. (2003). Continuous assessment: A practical guide for teachers. IEQ project, American Institutes for Research.

Kavaliauskienė, G., \& Darginavičienè, I. (2009). Dictation in the ESP classroom: A tool to improve language proficiency. ESP World, 8(2). Retrieved from http:/ / www.esp-world.info/Articles_23/issue_23.htm

Lado, R. (1964). Language teaching: A scientific approach. New York: McGraw-Hill.

Linde, A. (1991). Análisis de errores en las formas verbales inglesas en la producción escrita realizados por alumnos de la Universidad de Granada. Granada: Servicio de Publicaciones, Universidad.

Omaggio, A. (2000). Teaching language in context. Boston: Heinle and Heinle.

Panova, I., \& Lyster, R. (2002). Patterns of corrective feedback and classroom uptake in an adult ESL classroom. TESOL Quarterly.

Panolli, J. (2000). 'Aspects of the Corrective Contrastive Grammar' English-Albanian. Shtëpia Botuese e Librit Universitar: Tiranë.

Puhl, C. A. (1997). Develop, not judge: Continuous assessment in the ESL classroom. English Teaching Forum, 35(2), 2-9.

Reid, J. M., \& Byrd, P. (1998). Grammar in the composition classroom: Essays on teaching ESL for college-bound students. New York: Heinle \& Heinle.

Richards, J. C. (1974). A non-contrastive approach to error analysis. In Richards, J. (Ed.), Error analysis: Perspectives on second language acquisition. Essex: Longman.

Richards, J. C. (1971). Errors analysis and second language strategies. Language sciences Journal.

Richards, J. C. \& Sampson, G. P. (1974). The study of learner English. In J. C. Richards (Ed.), Error analysis. Perspectives on second language acquisition (pp. 318). London: Longman.

Shamiq. (2009). Si shkruhet vepra shkencore. Logos-A. Shkup, Prishtinë: Tiranë.

Tafani, V. (1999). Probleme psiko-didaktike të të shkruarit në gjuhën angleze në mjedisin shkollor shqiptar. Universiteti "Aleksandar Xhuvani:" Elbasan.

Tafani, V. (2002). "Të korrigjosh apo të mos korrigjosh" Buletini shkencor. Universiteti "Aleksandar Xhuvani:" Elbasan.

TeacherVision. (n.d.). Assessment vs. evaluation. Retrieved from http:/ / www.teachervision.fen.com/assessment/new-teacher/48353.htm

Trochim, W. M. K. (2006). Introduction to evaluation. Retrieved from http:/ / www.socialresearchmethods.net/kb/intreval.htm

Valero, L. A. et al. (2008). “Teachers' attitudes towards correcting students' written errors and mistakes."Porta Linguarum. 
Walvoord, B. F. (2004). Assessment clear and simple. A practical guide for institutions, departments and general education. San Francisco: Jossey-Bass.

Weinreich, U. (1953). Languages in contact. The Hague: Mouton.

Widdowson, H. G. (1978). Teaching language as communication. Oxford: Oxford University Press.

Zamel, V., \& Spack, R. (1998). Negotiating academic literacies. Teaching and learning across languages and cultures. Mahwah, NJ: Erlbaum.

\section{APPENDICES}

\section{Appendix 1. Error Checklist}

\begin{tabular}{|c|c|c|c|c|}
\hline $\begin{array}{l}\text { Error } \\
\text { Type }\end{array}$ & \multicolumn{4}{|c|}{ Part of Speech } \\
\hline \multirow{4}{*}{ 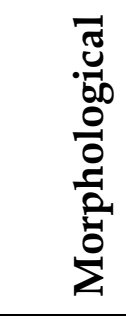 } & Verbs & $\begin{array}{l}\text { No. of } \\
\text { errors }\end{array}$ & Nouns & $\begin{array}{l}\text { No. of } \\
\text { errors }\end{array}$ \\
\hline & Tense & 85 & Articles/Determiners & 162 \\
\hline & Form & 74 & \multirow{2}{*}{$\begin{array}{l}\text { Noun endings } \\
\text { (Plural/Possessive) }\end{array}$} & \multirow[t]{2}{*}{67} \\
\hline & $\begin{array}{l}\text { Subject-Verb } \\
\text { Agreement }\end{array}$ & 41 & & \\
\hline \multirow{5}{*}{ ] } & Word choice & 63 & & \\
\hline & Word form & 26 & & \\
\hline & Informal usage & 7 & & \\
\hline & Idiom error & 3 & & \\
\hline & Pronoun error & 22 & & \\
\hline \multirow{3}{*}{ 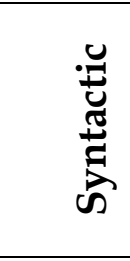 } & Sentence structure & 61 & & \\
\hline & Run-on sentences & 44 & & \\
\hline & $\begin{array}{l}\text { Fragment } \\
\text { sentences }\end{array}$ & 17 & & \\
\hline \multirow{2}{*}{ 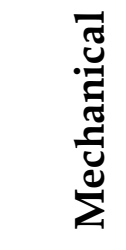 } & Punctuation & 128 & & \\
\hline & Spelling & 320 & & \\
\hline \multicolumn{4}{|c|}{ Total 891} & Total 229 \\
\hline
\end{tabular}


Language Testing in Asia

Volume one, Issue three

October 2011

Appendix 2: Students' compositions 200-250 words

- My town

My town is the most beautiful drool books city of all cities. I love my city because it have a lot of people, bit the lot of people are albanian and this is the Brice thing that makes me happy. But ounfort\$nately it have a lot of peoples that leave ss the town and goes to big cities. In las las time my town is called" the city of students" because in mycseity, we have two universities. He State University of Tetons and

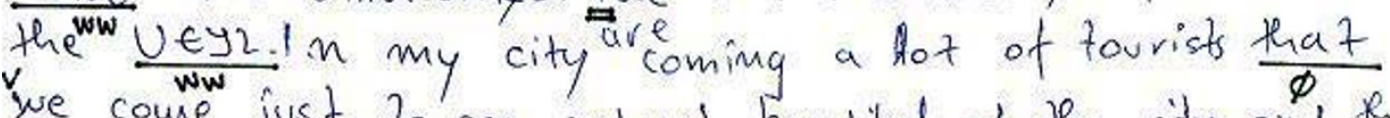
we come just to see natural beaubjul of the city and the other mF objects that ave characteristic WF of my town. Burt in my city are missing very things $\frac{\text { vert }}{w w}$ for $U$. But il I lope that in future everything will change and nothing me ts med and the you ger generatron will have a very amazing lifo full of happiness.

74 | P a ge 


\section{My best friend}

IH'm a friendly person and 7 have a lot of friends but II have a friend which I distinguisished from the others and she isainy "best friend Albuleng. she is like my sister that $I$ have never had 0 I love her very much and I trust her and we know each other secrets just like sisters. We always call each other no matter the hime to solve every problem if one of us have. She is ¿lovely.

17 Illfulena and me went to the cinema yesteraday afternoon. She goes to wothers ohops to buy elothes, like Germany Htaly i France,etc. She is also smartorich. But she does not show off intellectualy, financially, or enything from this sort. Im going to the half past seven every evening to call her for going out because I'm almost always busy too to ga out. Albulena is a Rood student "She likes pets and other animals. She has one cat. She lived in \& Gostivar. But sometimes she is a very naughty give. J like her and she likes me. When I invite her at my house she asks me to

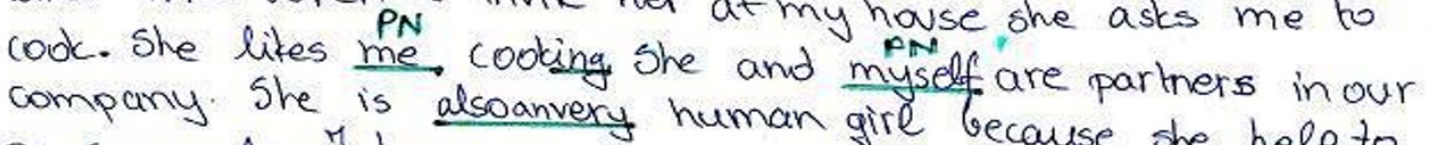
poor people. I hope that we will be friends she help to and will tell a strong supporting $\frac{b}{w w}$ friends forever

$$
\frac{w_{w}}{w} \text { a strong supporting cast to eachother. }
$$




\section{The zoo}

SV The zoo is the most beautiful thing for everyone. People goes inge:o for relaxing, to see, animals, to walle with friend ete. Kids,s when they Went to the zoo, they are so happy, PL becouse there will see the most of animals heard for them, but when they are there, symey will see i syn. and touch them. when J wasochild inodreams. $J$ saw the zoo, also I saw when J takel care for animils, J Leed them

This place is Omagic, who make people, especially kids to feel good to be happy and to wakeofrom them the boring feels. When we are there, walked around the zoo, ware? are talking with unknown people about the years of the damgerous animals in the zoo. AWK 


\section{My faronite movic}

T) like action movies. My farorife movie is "Forro". Sashleim and $P$ we went to the cinema yesterday affermoon and we see the movie $\frac{\text { caled }}{\text { sp }}$ "Fono". The main caracter in this marie is forro. Jono is a brave man. Thisoes a forwer king. Iono is a big mam and angood man. He is to smant and nonrbody can sperent escape from him, and he he hef evenybody who hare trubles. Norbody can be like him because fou need to have no scare from nothing and now-
body. Ij like this movie because it is my farorite. 
In the garden of my city

I live in a beantiful city called Gostivan. It is a small city, under development, but OIS Ogresto surranded wich mountains. There is a beantiful

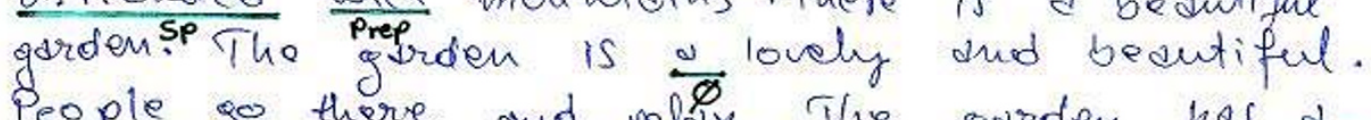
People go there and veldx. The gerden has d their trees. Usuallyochildren and ofd poople $\frac{\text { dat }}{v r}$ why women in $\frac{14}{8}$ chilting are in the garden

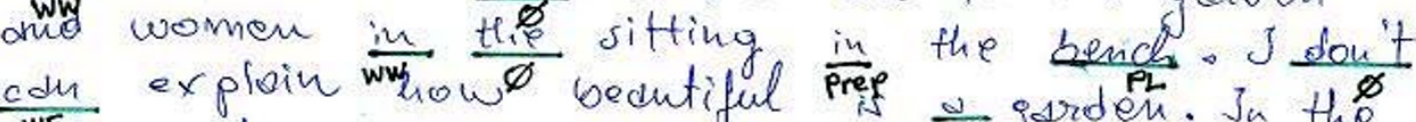

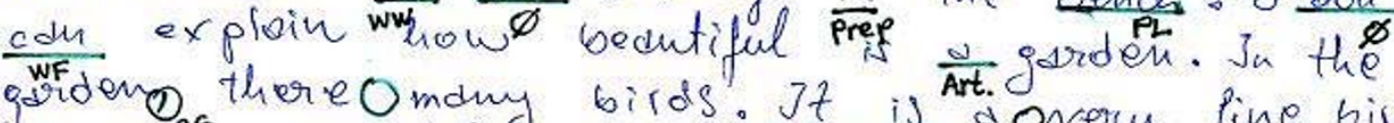

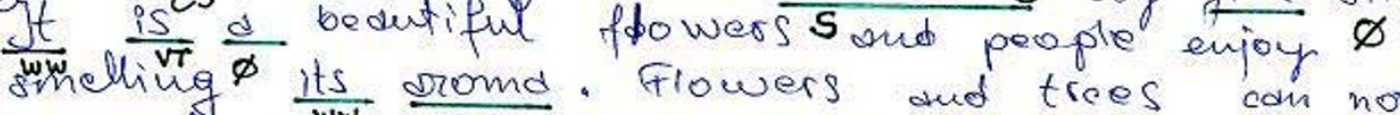
be cut by people te at people should take care dbont the finviroIment in thein country, and that's how they will live a better life in in the future. I would like to invite people from onother city to come and visit my countryis gorden in Gostiver and enjoy with theirw family its beduty and reldrocs and above alfoforget all the worries for the rest of the csworld. 


\section{The 200}

When I was a little girles my parents took me to the 200. The 200 is in the Shkupi. The zoo is wa near the I saw the lion's avisit to the 2008 near the tiger's cage. Last month cage. He $\bar{\varnothing}$ told me that he friend. We visit to the lion's yesterday. He said othat monkeys are very friendly and
even more when you gave them even more when you gave them something to eat.
after we visit the monkey's cage, we went to
another place. While we were walking we sau that there while we were walking we saw lots of Giraffas and zebnas as well. Lots of people were senjoying the beautiful view surrounded with animals and children the most There were a very happy to see their favowite

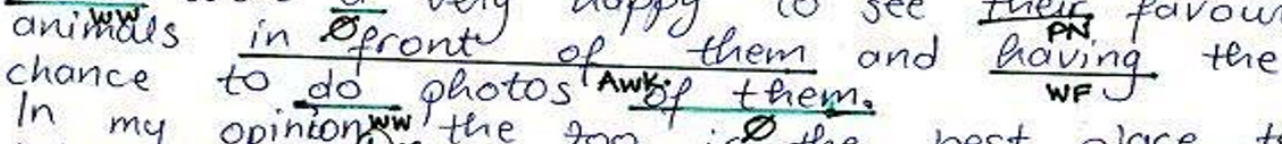
take childinen fopor 200 is the best place to for their animal smites on their faces wondering of it, just like in $\frac{a}{\varnothing}$ cartoons. 
Appendix 3: The following tests were delivered to 50 students of the English Department at State University of Tetova.

(Nouns-Confusion of numbers)

Exercise nr.1: Give the correct number, is or are, in the following:

1. The news I received good.

2. Where the money?

3. Maths my favourite subject.

4. Eating fish is very healthy.

5. The sheep grazing in the field.

Exercise nr.2: Write sentences showing whether the following nouns can be used in the singular or in the plural:
1. news
4. furniture
2. money
5. knowledge
3. advice

(Adjectives-Comparative or Superlative)

Exercise nr.3: Rewrite the following with the correct adjectives in brackets:

1. He's the (strong) boy in the whole school.

2. Of the two sisters, Mary is the (beautiful).

3. Ann is the (young) of four sisters.

4. This is the (good) book I've ever read.

5. Which of the two girls is (tall)?

Exercise nr.4: Use many or much in these sentences:

1. He hasn't money.

2. Have they books?

3. There isn't food in the house.

4. I haven't time.

5. How does this book cost?

(The articles-definite and indefinite)

Exercise nr.5: Fill in the blanks with a or an where necessary:

1. Swimming is great fun.

2. The plane made terrible noise.

3. What sort of pupil is he?

4. The train left half

5. She's clever girl.

Exercise nr.6: Fill in the blanks with the where necessary:

1. My little brother will go to school next year.

2. r red, blue, and green are beautiful colors.

3. What time is lunch?

4. She can speak French.

5. __ flies are harmful insects.

(Use of the appropriate tense)

Exercise nr.7: Supply the correct tense, Present Simple or Present Continuous, in the following:

1. I (to go) to school every day.

2. He (to go) to the school now. 
3. Look! They (to come) towards us.

4. We (to go) to the cinema this evening.

5. I usually (to eat) fresh fruits.

(Third person singular)

Exercise nr.8: Put the following into the third person singular, present tense:

1. I always do my homework carefully, but Mike never

2. I haven't got a new computer, but Rosie

3. She walks to work everyday, but her husband

4. Robin has a broken arm, but Carol

5. I go to school by bike, but my friend

Appendix 4: A list of the most common occurring errors (misused forms and incorrect omissions) of Albanian students:

(Using the wrong prepositions)

1. Accuse for (instead of accuse of)

2. Afraid from (instead of afraid of)

3. Arrive to (instead of arrive at)

4. Believe to (instead of believe in)

5. Complain for (instead of complain about)

6. Composed from (instead of composed of)

7. Congratulate for (instead of congratulate on)

8. Depend from (instead of depend on)

9. Fail from (instead of fail in)

10. Full from (instead of full of)

(Misuse of the infinitive)

1. without to speak (instead of without speaking)

2. capable to do that (instead of capable of doing that)

3. fond to talk (instead of fond of talking)

4. prevented me to go (instead of prevented me from going)

5. think to go to England (instead of think of going to England)

6. used to get up (used to getting up)

7. avoid to make (avoid making)

8. enjoy to play (enjoy playing)

9. object to be treated (object to being treated)

10. succeed to win (succeed in winning)

(Incorrect omissions-omission of prepositions)

1. ask a thing (instead of asking for a thing)

2. dream a thing (instead of dreaming of a thing)

3. explain a person (instead of explain to a person)

4. listen a person (instead of listen to a person)

5. pay a thing (instead of paying for a thing)

6. remind a person something (remind a person of something)

7. reply a person (reply to a person)

8. remind a person something (instead of remind a person of something)

9. speak a person (instead of speak to a person)

10. wish a thing (wish for a thing) 


\section{Appendix 5. Interviews}

Interview 1. Wrong Infinitive

\begin{tabular}{|c|l|}
\hline 1. & I can to swim very well \\
\hline 2. & I could not to see you yesterday \\
\hline 3. & May I to visit you next weekend \\
\hline 4. & Shpendi's father would not let him to go out \\
\hline 5. & You can't make her to understand \\
\hline 6. & They saw him to leave the house \\
\hline 7. & I watch the girls to play hockey \\
\hline 8. & We hear him to speak in English \\
\hline 9. & I could feel her heart to beat \\
\hline
\end{tabular}

Interview 2(a). Wrong grammatical tense

(On-the-spot translations from Albanian into English)

\begin{tabular}{|c|c|c|}
\hline Nr. & Albanian & Wrong translation in English \\
\hline 1. & Unë studioj Anglishten & I am studying English \\
\hline 2. & Ndjehem shumë mirë & I am feeling very well \\
\hline 3. & Nuk dëgjoj asgjë & I am not hearing anything \\
\hline 4. & A mësoni Anglisht? & Learn you English? \\
\hline 5. & Ai duhet të vij & He must to come \\
\hline 6. & Ç'farë po bën tani? & What do you do? \\
\hline 7. & Ai është i sëmurë që nga shkurti & He has been ill since February \\
\hline 8. & Ata u takuan në Paris & They have met in Paris \\
\hline 9. & Dielli sapo perendonte kur arritëm tek ura & The Sun set when we reached the bridge \\
\hline 10. & $\begin{array}{l}\text { Kur ne arritëm, ndeshja tashmë kishte } \\
\text { filluar }\end{array}$ & $\begin{array}{l}\text { When we arrived, the match already } \\
\text { started }\end{array}$ \\
\hline 11. & Ai shkoi shumë më parë se të arrinte letra & He went before the letter came \\
\hline 12. & $\begin{array}{l}\text { Kur arritën në stacion, konstatoi se shokët } \\
\text { posa kishin arritur }\end{array}$ & $\begin{array}{l}\text { On reaching the station, he found that his } \\
\text { friends already arrived }\end{array}$ \\
\hline 13. & $\begin{array}{l}\text { Athua çka do të jetë duke bërë në këtë kohë } \\
\text { nesër }\end{array}$ & $\begin{array}{l}\text { I wonder what will he do this time } \\
\text { tomorrow }\end{array}$ \\
\hline 14. & $\begin{array}{l}\text { Kur të arrij në shtëpi, familja ime ndoshta } \\
\text { do të shikon televizionin }\end{array}$ & $\begin{array}{l}\text { When I get home, my family probably is } \\
\text { watching television }\end{array}$ \\
\hline 15. & Unë do t’i bëj ushtrimet e mia & I shall do my exercises \\
\hline 16. & Ajo do të bëhet mjeke & She will be a doctor \\
\hline 17. & A do t'i vizitoni? & Will you visit them? \\
\hline 18. & $\begin{array}{l}\text { Nuk do të përgjigjem në të gjitha këto } \\
\text { pyetje }\end{array}$ & I will not answer to all questions \\
\hline 19. & Ndërtesa e re do të ketë dhjetë kate & This new building will have ten floors \\
\hline 20. & Duhet tash ta shkruani atë & You should write it now \\
\hline 21. & Duhet të keni më tepër durim & You must have more patience \\
\hline
\end{tabular}


Interview 2(b). Wrong grammatical tense

(On-the-spot translations from English into Albanian)

\begin{tabular}{|c|c|c|}
\hline Nr. & English & Wrong translation in Albanian \\
\hline 1. & He has lived on this street for a long time & $\begin{array}{l}\text { Ai ka jetuar në këtë rrugë për një kohë } \\
\text { të gjatë }\end{array}$ \\
\hline 2. & We have known each other for years & $\begin{array}{l}\text { E kemi njohur njëri tjetrin me vite të } \\
\text { tëra }\end{array}$ \\
\hline 3. & How long have you been here? & Sa kohë ka që keni qenë këtu? \\
\hline 4. & $\begin{array}{l}\text { I have been waiting for you nearly half an } \\
\text { hour }\end{array}$ & Jam duke të pritur më se gjysmë ore \\
\hline 5. & We have been talking for more than an hour & $\begin{array}{l}\text { Kemi qene duke biseduar për më se një } \\
\text { orë }\end{array}$ \\
\hline 6. & Have you been working long? & A keni punuar për një kohë të gjatë? \\
\hline 7. & $\begin{array}{l}\text { We have been living here since we got } \\
\text { married }\end{array}$ & $\begin{array}{l}\text { Ne kemi jetuar këtu që kur jemi } \\
\text { martuar }\end{array}$ \\
\hline 8. & $\begin{array}{l}\text { We had been walking for two hours before we } \\
\text { saw the first house }\end{array}$ & $\begin{array}{l}\text { Ne shetitëm dy orë para se ta shihnim } \\
\text { shtëpinë e parë }\end{array}$ \\
\hline 9. & $\begin{array}{l}\text { The day before they came, it had been raining } \\
\text { for hours }\end{array}$ & $\begin{array}{l}\text { Ditën para se të vinin, kishte ra shi me } \\
\text { orë të tëra }\end{array}$ \\
\hline 10. & I am going to work after lunch & Unë po shkoj të punoj pas drekës \\
\hline 11. & He is going to sell his car & Ai shkon të shes automobilin e vet \\
\hline 12. & Are you going to see her soon? & $\begin{array}{l}\text { A do të shkoni të shiheni me te së } \\
\text { shpejti? }\end{array}$ \\
\hline 13. & I am going to buy new shoes for the dance & Po shkoj të blej këрuсё të reja për ballo \\
\hline 14. & I am to see him tomorrow & Jam për ta parë atë nesër \\
\hline 15. & Are you to go now? & A jeni për të shkuar tani? \\
\hline
\end{tabular}

Interview 3. Omitting the preposition

\begin{tabular}{|l|l|l|}
\hline Nr. & Albanian & English \\
\hline 1. & Sa pagove për librin? & How much did you pay the book? \\
\hline 2. & Të lutem ma përkujto atë më vonë & Please remind me that later \\
\hline 3. & Shoku im ndau librin e tij me mua & My friend shared me his book \\
\hline 4. & Do të pres te kinemaja & I'll wait you at the cinema \\
\hline 5. & Do t'i shkruaj asaj nesër & I'll write her tomorrow \\
\hline
\end{tabular}

Interview 4. Unnecessary prepositions

\begin{tabular}{|l|l|l|}
\hline Nr. & Albanian & English \\
\hline 1. & Të lutem përgjigju në pyetjen time & Please answer to my question \\
\hline 2. & Mos iu afro asaj shtëpie! & Don't approach to that house! \\
\hline 3. & E pyeta arsimtarin për atë çështje & I asked to the teacher about it \\
\hline 4. & Libri përmban pesë kapituj & The book comprises of five chapters \\
\hline 4. & Ne hyrëm në klasë & We entered into the classroom \\
\hline 5. & Ylli u largua nga Britania javën e kaluar & Ylli left from England last week \\
\hline
\end{tabular}




\begin{tabular}{|l|l|l|}
\hline 6. & Ne arritëm herët në shkollë & We reached to the school early \\
\hline 7. & A i ngjanë ajo babait të saj? & Does she look like to her father? \\
\hline 8. & Toka sillet rreth diellit & The Earth goes round of the Sun \\
\hline 9. & I thash të vij menjëherë & I told to him to come at once \\
\hline
\end{tabular}

Interview 5. Unnecessary articles

\begin{tabular}{|l|l|}
\hline 1. & The Shpendi will go to England \\
\hline 2. & The Shakespeare's tragedies are famous \\
\hline 3. & The bravery is a great virtue \\
\hline 4. & The gold is a precious metal \\
\hline 5. & The dogs are faithful animals \\
\hline 6. & Shpendi speaks the English very well \\
\hline 7. & I will eat the breakfast \\
\hline 8. & My favourite game is the football \\
\hline 9. & The flu is a shameful disease \\
\hline 10. & The blue is a beautiful colour \\
\hline 11. & My sister goes to the school \\
\hline 12. & On Sunday I go to the church \\
\hline 13. & The nature is beautiful in spring \\
\hline 14. & A thief is a danger to the society \\
\hline 15. & You must be careful in the future \\
\hline 16. & Driton has found the work at the bank \\
\hline
\end{tabular}

Interview 6. Putting adverbs in an incorrect order

\begin{tabular}{|l|l|}
\hline 1. & I go always to the cinema \\
\hline 2. & They usually are at home \\
\hline 3. & I always have enjoyed singing \\
\hline 4. & I never should have eaten so much \\
\hline 5. & It often is warm in Macedonia \\
\hline 6. & I get up usually at 7 a.m. \\
\hline 7. & John never has been to London. \\
\hline 8. & We go often to the cinema. \\
\hline 9. & They always are happy to see us. \\
\hline 10. & I always have been a keen gardener. \\
\hline 11. & You should have never told him. \\
\hline 12. & I constantly am learning new words. \\
\hline
\end{tabular}

Interview 7. Confusing words

\begin{tabular}{|l|l|}
\hline 1. & Mary and me went to the library \\
\hline 2. & He spoke to John and I. \\
\hline 3. & He is better than me. \\
\hline 4. & It was me who did it. \\
\hline
\end{tabular}




\begin{tabular}{|l|l|}
\hline 5. & Who is it? - It's I. \\
\hline 6. & They spoke to Arthur and I. \\
\hline 7. & Mary and me went out to dinner last night. \\
\hline 8. & Me and John had an argument. \\
\hline 9. & I have known him since a long time. \\
\hline 10. & I haven't seen him since ages. \\
\hline
\end{tabular}

Interview 8. Confused prepositions

\begin{tabular}{|l|l|}
\hline 1. & We come at school every morning \\
\hline 2. & Someone is standing to the door \\
\hline 3. & Lumi has a flat at Paris \\
\hline 4. & My uncle will arrive at Saturday \\
\hline 5. & I usually get up on seven o'clock \\
\hline 6. & She goes for a walk at the afternoon \\
\hline 7. & I bought a book at 50 denars \\
\hline 8. & I can't buy it for such a high price \\
\hline 9. & Divide the apple between you three \\
\hline 10. & There was a fight among two boys \\
\hline 11. & Gëzim was standing just besides me \\
\hline 12. & The man shot the bird by a gun \\
\hline 13. & Shpresa was punished from her father \\
\hline 14. & He's the tallest from all the boys \\
\hline 15. & The teacher spoke for bad habits \\
\hline 16. & Ahmedi's been ill from last Friday \\
\hline 17. & I may be able to go after a week \\
\hline 18. & I'll come back in an hour \\
\hline
\end{tabular}

Interview 9. Confused verbs

\begin{tabular}{|l|l|}
\hline 1. & I will go tomorrow if it's fine \\
\hline 2. & He shall go if he has permission \\
\hline 3. & You must make your homework carefully \\
\hline 4. & I'm going to lay down for an hour \\
\hline 5. & Please lie the exam papers on the desk \\
\hline 6. & We seat at a desk to write a letter \\
\hline 7. & He sat the passengers one by one \\
\hline 8. & The teacher said to rise up the hand one who knows the answer \\
\hline 9. & I like you! Will you marry me? \\
\hline 10. & We remained in a very good hotel \\
\hline 11. & Not many apples have stayed on the branch \\
\hline 12. & When I grow I'll be a doctor \\
\hline 13. & These flowers grow up very quickly \\
\hline 14. & I want to lend a book from you \\
\hline
\end{tabular}




\begin{tabular}{|l|l|}
\hline 15. & Someone has robbed all her money \\
\hline 16. & I am persuaded of Shpendi's innocence \\
\hline 17. & Blerta denied to take the money \\
\hline 18. & She wins her living by hard work \\
\hline 19. & Gëzim learned us how to play football \\
\hline 20. & The teacher accepted to go with us \\
\hline 21. & The ship drowned in the ocean \\
\hline 22. & Nehat was seeing out of the window \\
\hline 23. & I was hearing her CDs \\
\hline 24. & Please remember me to give it back \\
\hline 25. & I'll sleep early tonight \\
\hline 26. & Genci took a good mark in Chemistry \\
\hline 27. & Do you like to see my collection? \\
\hline 28. & Artani is learning at State University of Tetova \\
\hline 29. & Rita took out her hat and coat \\
\hline 30. & I've now left football \\
\hline 31. & Jeta fall down and broke her leg \\
\hline 32. & Jeta tried to found her lost book \\
\hline
\end{tabular}

Interview 10. Confused adverbs

\begin{tabular}{|l|l|}
\hline 1. & He sounds angry \\
\hline 2. & John looked quick at his watch \\
\hline 3. & Do you feel well about your new job? \\
\hline 4. & It's too hot in Spain in the summer \\
\hline 5. & It's now very hot to play football \\
\hline 6. & He's a much strong man \\
\hline 7. & He's very stronger than I am \\
\hline 8. & She likes the cinema too much \\
\hline 9. & I saw your friend before two weeks \\
\hline 10. & She rubbed her eyes hardly \\
\hline 11. & I hear that he's not so rich \\
\hline
\end{tabular}

Interview 11. Confused adjectives

\begin{tabular}{|l|l|}
\hline 1. & I have a lovely black white jumper \\
\hline 2. & The tea was nice hot \\
\hline 3. & The hat was green red blue yellow \\
\hline 4. & My brother hasn't much books \\
\hline 5. & She gave an apple to every of the children \\
\hline 6. & Each child had an apple \\
\hline 7. & She got to school latter than I did \\
\hline 8. & He's been sick for over a year \\
\hline
\end{tabular}




\begin{tabular}{|l|l|}
\hline 9. & Our teacher is very nervous today \\
\hline 10. & You should keep your hands clear \\
\hline
\end{tabular}

Interview 12. Confused nouns

\begin{tabular}{|l|l|}
\hline 1. & You should go to your house now \\
\hline 2. & I like to sit in the shadow \\
\hline 3. & Our travel to Mitrovica was lovely \\
\hline 4. & I hurt my foot \\
\hline 5. & I have a poetry to learn by heart \\
\hline 6. & They had a nice play of football \\
\hline 7. & There were five individuals in the shop \\
\hline 8. & The man took his woman with him \\
\hline 9. & What's the prize of this watch? \\
\hline 10. & When I entered the room, I saw a book on the ground \\
\hline
\end{tabular}

Interview 13. Confused plural

\begin{tabular}{|l|l|}
\hline 1. & Mathematics are fascinating \\
\hline 2. & The police is here \\
\hline 3. & The news are at 7 o'clock \\
\hline 4. & There is an apple and two oranges in the fridge \\
\hline 5. & Physics are fun \\
\hline 6. & Neither of the cars are suitable \\
\hline 7. & The committees has made its decision \\
\hline 8. & A number of changes has been made \\
\hline 9. & Vigan gave me some good advices \\
\hline 10. & Can you give me any informations? \\
\hline 11. & Furnitures are often made of wood \\
\hline 12. & Her luggages are at the station \\
\hline 13. & Today I've many works to do \\
\hline 14. & That man has long hairs \\
\hline 15. & Breads are sold at the baker's \\
\hline 16. & Yesterday we had fishes for dinner \\
\hline 17. & Ten sheeps are grazing the field \\
\hline 18. & All her money are kept in the bank \\
\hline
\end{tabular}

Interview 14. Confused parts of speech

\begin{tabular}{|l|l|}
\hline 1. & You don't look as your mother \\
\hline 2. & It's such small that you can't see it \\
\hline 3. & I've never seen a so large animal before \\
\hline 4. & I've not made any mistakes in dictation \\
\hline 5. & I found all the windows opened \\
\hline
\end{tabular}




\begin{tabular}{|l|l|}
\hline 6. & Shpendi behaves friendly \\
\hline 7. & Is it truth that Shpendi is very ill? \\
\hline 8. & The others boys aren't here \\
\hline 9. & I think his grandfather is died \\
\hline 10. & I had a good shoot at the goal \\
\hline 11. & The bird was feeding it's young \\
\hline 12. & I pain in my leg \\
\hline 13. & My bicycle worths $\$ 200$ \\
\hline 14. & The poor man doesn't able to pay \\
\hline 15. & Shpendi doesn't afraid of anybody \\
\hline 16. & The singer sings very good \\
\hline 17. & The little girl sang beautiful \\
\hline 18. & After we went home for dinner \\
\hline 19. & I've seen and the two of them \\
\hline 20. & She doesn't trust and her friends \\
\hline 21. & Be careful not to loose your money \\
\hline 22. & I past by your house yesterday \\
\hline
\end{tabular}

Appendix 6: Find a mistake.

Directions: There is one erroneous word or phrase in each sentence below. Identify the mistakes and correct them.

\section{Test 102}

1. Cultural historians point out that acquisition of consumer goods, which had been scarce during wartimes, became a central feature of postwar life.

2. From Montreal to Lake Ontario, St. Lawrence River rises $68 \mathrm{~m}$ in elevation and has several regions of rapids.

3. In the 19th century, Canada constructed canals and locks to allow commercial vessels navigating this par of the river, and by 1900 all of the component water ways had a minimum depth of $4 \mathrm{~m}$.

4. Lack of food forced the party turn back within $179 \mathrm{~km}$ of the pole.

5. No one knows exactly how many species are being lost because nobody of us knows exactly how many species exist on Earth.

6. They became the chief European traders with the Iroquois, supplying them with firearms, blankets, metal tools, and other European trade goods for exchange of furs. 7. Amundsen originally sought the North Pole, but when that had been conquered in 1909 he set his sights on the South Pole.

8. He together with his companions were ready for the journey; they set out from the Bay of Whales on the Ross Ice Shelf near Roosevelt Island just four days before Scott's team began their journey.

9. Trucks are usually larger and more heavier than automobiles and differ in basic construction.

10. Double trailers resemble two smaller trailers linked to gether and can maneuver through tight turns more easily than standard trailers do. 
11. Some of today's dolls walk and have facial expressions that change, hairs can be repeatedly washed and styled because each strand is firmly embedded in the scalp. 12. There was something in his low, languid voice that was absolutely fascinated.

13. In the United States the cabinet consists of the president's advisers, each of whose is a department head.

14. Firstly cultivated in South America, the cacao tree was introduced Into Europe during the 16th century.

15. Because you have the most marvelous youth, and youth is the one thing worth to have.

\section{Test 103}

1. During War II, Miami has served as a major military training area, and thousands of soldiers settled in the area after the war ended in 1945.

2. The strongest tornadoes may sweep houses from their foundations, destroy bricks buildings, toss cars and school buses through the air, and even lift railroad cars from their tracks.

3. The moment I met you I saw that you were quite unconsciously of what you really are, of what you really might be.

4. If a cabinet lacks either legislative or popular support, the government said to fall, and the executive must form a new cabinet capable of winning the required support.

5. But she felt afraid of him, and ashamed being afraid.

6. If caught outside by a hurricane, a person should lie flatly in a ditch and cover his or her head for protection from flying debris.

7. I never talk when I am working, and never listen too, and it must be dreadfully tedious for my unfortunate sitters.

8. In 1642 Pascal created a machine to get free his father, who was a tax collector, from the tedious task of adding columns of numbers.

9. Let us have something icing to drink, something with strawberries in it.

10. She could not help to like the tall, graceful young man who was standing by her.

11. For nearly ten minutes he stood there, motionlessly with parted lips, and eyes strangely bright.

12. The captain handed me his binoculars. Through it I could see three small boats rising and falling on the long Pacific swells.

13. Unless they don't resign, cabinet members serve for the duration of the term or terms of the president who appoints them.

14. He felt as if a hand of ice had been lain upon his heart.

15. It is rather late, and, as you have to dress, you would better lose no time.

Test 102 (Results)

Students tested -50

\begin{tabular}{|l|l|l|}
\hline Q\# & Correct & Wrong \\
\hline 1. & 5 & 45 \\
\hline 2. & 0 & 50 \\
\hline 3. & 0 & 50 \\
\hline 4. & 6 & 44 \\
\hline 5. & 2 & 48 \\
\hline 6. & 0 & 50 \\
\hline
\end{tabular}




\begin{tabular}{|l|l|l|}
\hline 7. & 2 & 48 \\
\hline 8. & 0 & 50 \\
\hline 9. & 2 & 48 \\
\hline 10. & 1 & 49 \\
\hline 11. & 12 & 38 \\
\hline 12. & 6 & 44 \\
\hline 13. & 0 & 50 \\
\hline 14. & 5 & 45 \\
\hline 15. & 1 & 49 \\
\hline
\end{tabular}

\section{Test 103 (Results)}

Students tested - 50

\begin{tabular}{|l|l|l|}
\hline Q\# & Correct & Wrong \\
\hline 1. & 0 & 50 \\
\hline 2. & 7 & 43 \\
\hline 3. & 3 & 47 \\
\hline 4. & 4 & 46 \\
\hline 5. & 6 & 44 \\
\hline 6. & 1 & 49 \\
\hline 7. & 0 & 50 \\
\hline 8. & 1 & 49 \\
\hline 9. & 0 & 50 \\
\hline 10. & 6 & 44 \\
\hline 11. & 1 & 49 \\
\hline 12. & 1 & 49 \\
\hline 13. & 0 & 50 \\
\hline 14. & 1 & 49 \\
\hline 15. & 0 & 50 \\
\hline
\end{tabular}

